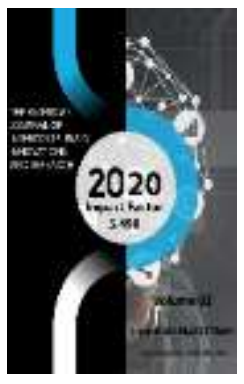

Journal Website: http://usajournalshub.c om/index,php/tajiir

Copyright: Original content from this work may be used under the terms of the creative commons attributes 4.0 licence.

\section{The National Intelligentsia Of The Late XIX - Early XX Centuries: On The Work Of Is'hakhon Ibrat "Historical Culture"}

\author{
Vohidova Komila Abdullozizovna \\ Associate Professor, Department Of Social Sciences, Namangan Institute Of Engineering And \\ Technology, Namangan, Uzbekistan
}

\title{
ABSTRACT
}

The study and compilation of written sources are important when studying the problems of the sociopolitical, economic, spiritual and cultural life of our people in the past and enriching the research power. Today, the study of sources in many collections of manuscripts is the centre of attention of historians and researchers. The manuscript "Historical Culture" by Is'hakhon Junaidullohhoja oglu Ibrat (1862-1937), reflecting the requirements of historical development, as important as the spiritual heritage of the first 30 s of the twentieth century [1]. The performance touches on the problems of culture, analyses its future development and reflects the real situation in Turkestan in this area. During this period, priority will be given to the most relevant issues of science, education and education, education and new schools, schools for girls, higher education institutions and their benefits for the country.

\section{KEYWORDS}

Compulsory education, Culture, Development, Economics, Education, Expression, Illiteracy, Language, Light Industry, Manuscript, Material, medicinal plants, Paper, primary education, school, Science, Source, Spiritual.

\section{INTRODUCTION}

In particular, the work of the Jadids of the late XIX - early XX centuries in this area, his writings, the ideas of the desire to develop the culture of the East and West while preserving national 
identity. Jadids at one time take seriously the problems of science, school, education, cultural development, develop these problems for the development of the nation in accordance with the requirements of the times, try to solve them. Throughout his career, Is'hakhon considered science and education a primary need for the development, growth and development of the country. In Jadid writings and articles, the word "culture" is often used to mean "progress." This feature is also characteristic of the work of Ibrat, which is divided into three parts: the note, the main part and the conclusion. In the introductory part, the author recognizes that the purpose of writing the brochure, apologizing to the reader, is to expand people's views on cultural progress and decline, to explain the essence of progress.

The peculiarity of literature written in the second half of the 1920 s is that, although these works retain national features, they are not surrounded by a chain of dominant ideologies, but its influence is reflected in the comments made to the facts. Doctor of Historical Sciences, Professor D.A. Alimova notes that the study of the history of the culture of this period is "the most difficult and controversial period in the history of cultural development, and this feature was reflected in the historical literature on this issue" [2]. He also periodically divides the study of cultural problems up to 30 years into two stages. Firstly, the period from the beginning of the twentieth century to the October Revolution. Secondly, the period from 1917 to the mid-30s. In particular, it is concluded that the study of cultural problems went in the scientific and journalistic direction.

\section{MATERIALS AND METHODS}

At the turn of the century, the Jadids worked to create the material and spiritual basis of an independent state. Such ideas and views were put forward in scientific articles $[3,4,5,6,7,8$, 9] by Is'hakhon of this period and in his works $[10,11,12,1]$, in which science, education, the school will pay special attention to education issues and will analyse ways to improve it. In the pamphlet, "Historical Culture," Is'hakhon comments on the material and spiritual basis of an independent state. In this case, his long stay in foreign countries, his close acquaintance with science, technology, social life, language and religion of this country brings great benefits. The brochure has not yet been used as a source of research, including two copies in the manuscript fund of the Beruni Institute of Oriental Studies, which are not yet known to the general public. Both copies are on the same cover as Ibrat's "History of Ferghana”. The first work is Q-inv. Stored at 611616, hardcover, 20 sheets, 40 pages. At the end of the manuscript, the date of writing is indicated as $1344 \mathrm{AH}$ and 1926 AD. At the end of the treatise, Ibrat writes: "I completed it in 1344 AH, January 10, 1926 AD" $[1$, p. 139]. The second copy of the brochure handwritten fund inv. Stored under number No. 10117. The cover is hard, 18 sheets, 36 pages, 2 pages left blank. On the last page of the work, it is indicated that it was completed in 1925 and 1344 according to the hijra. On the last page of the work, it is indicated that it was completed in 1925 and 1344 according to the hijra. In this copy, the words "1344 AH, 1925 A.D., completed," written by Ibrat, were written at the end of the second part of the work, the Attention section. [1, p. 106] Based on the comparison of the letter of the treatise, we can say that it was copied by the calligrapher Inoyathan Turakurgani, who copied Ibrat's work "The History of Ferghana." The copy we are studying in the 2nd copy, on the last page of which there are also inscriptions "1374 hijra and 1955 AD." From these records, we can conclude that this copy was copied in 1955 by calligrapher Said 
Naimhan Tora Turakurgani, who copied the "History of Ferghana" by Ibrat [1, p. 138]. Both works are written in Arabic graphics, in alphabetic type. Initially, the brochure was completed before the October Revolution of 1917, but since it was lost in print, Ibrat returned it to his generation in 1925 as memories of Islam [1, p.114]. In the introduction to the main part of the work, he defines the word "culture" and focuses on the language problem, which is still the subject of numerous disputes and disputes. Concerned that at the beginning of the century phrases turned into a mixed language, the author was dissatisfied with the fact that his parents were Turks, the city was Turkish, the population spoke Persian, and Russian, Turkish and Arabic were mixed. It is said that this culture came to Turkestan from Iran. [1, p. 109]

This problem, posed by Ibrat in his work, is one of the main tasks facing scientists, terminology scholars and lexicographers today to restore the charm of the Uzbek language.

Ibrat's trips abroad influenced him, and during this time his worldview changed dramatically, realizing the difference between the West and the East. During this time, he will get acquainted with developing facilities of developed countries and cities, intends to introduce them in the country, to facilitate the lifestyle of his people. For this, first of all, science understands the need for technology, shows the way forward. In particular, he lists the objects that he saw in foreign cities, from mosques and madrasas, benefits for military service, savings banks, round-the-clock shops, schools, penitentiaries, and ending with the small social conditions necessary for the population. He describes a city that has achieved culture as follows: "The word culture is governed by law and order, and if people know the science and profession and live happily in their profession, then the land is called a city, and its inhabitants are civilized" [1, p. 109]. Among the culturally developed cities, the author includes Petrograd, Moscow, Odessa from Russia, Berlin, Madrid, London from Europe, Rome, Washington, Tokyo, Istanbul and other large and small cities from the east. To identify the reasons for the development of model cities, he asked himself how did these developed cities achieve culture? After studying science, he concluded that his people had achieved culture only by making the pen a tool for themselves. There is no farming without a hoe, there is no harvest without a sickle, there is no weaving without a shop, they need tools. Since science is a tool that finds and drives culture, it is necessary to master it [1,p .112-113].

With these thoughts, Ibrat points to illiteracy and ignorance as to the main cause of underdevelopment, social and colonial oppression in Turkestan. To prevent this, it is first necessary to develop the socio-economic life of the country and create a unique concept in this regard.

In the pamphlet, Ibrat understands the relationship between the village and the city as one of the material foundations of an independent state, considers it necessary to narrow the gap between them and recognizes that the situation of villages in the country is difficult. To show that the city and the village are inseparable, that they can achieve interdependent development, he approaches the problem, on the other hand, saying that the affairs of the village related to the city, the affairs of the city to the village, they are inseparable. He stressed that the needs of the city should be met at the expense of the village, the needs of the village should be met at the expense of the city, and this should meet the needs of each other based on public life. The 
need to pay attention to this is emphasized. [1, p. 115-116]

In the pamphlet, Ibrat is interested not only in the social problems of the village but also in the economic problems of the country. He said that for the development of the economy, first of all, it is necessary to solve the water problem, adding that the crops grown in villages are not enough for the population, there is land for harvesting, but a problem with water. He argues that it is impossible to create a farm without water, and that water can lead these farms to development if possible.

Therefore, for Fergana, nothing is more important than the need for water, because we have a lot of lands, we have little water, this region is the land that drinks water from the mountains, and not from the river. If it is possible to bring water to the northern part of Namangan, it will be possible to grow different crops here. [1, p. 116-117] With these thoughts, Ibrat recognizes that the construction of water bodies, the issue of water supply is an important issue in the daily life of the country.

Another problem worrying about the village, he considers the increase in unemployment. He referred to illiteracy in rural areas, the low literacy rate in rural areas and the ignorance of peasants who live in terrible conditions as a result of subsistence farming. causes. At least he criticizes them for not being interested in studying in their free time from agriculture, for spending their lives idle, and for losing themselves to make more money from science. Thus, Ibrat implies that the situation of farmers is getting worse and worse and that they need to further strengthen their entrepreneurship through science. Ibrat considers the creation of the food industry as another economic problem and proposes to build sugar and tea plants here. Therefore, given the special role of paper production in the development of the country's industry, Is'hakhon said that in our cities there is a great need for paperwork, everything is ready, it would be good to have a paper mill suitable for large-scale production. Also, it is possible to use and build a factory throughout the year, given that such a factory was in Kokand and has now ceased to operate.

The brochure also addresses the production of light industry as a developing industry in the country. He noted that during this period, light industry goods were produced in the country, but these industrial goods, including shoes, carpets, mats and shawls, were expensive because they were made manually, and that people would buy more imported factory goods. explains that it is necessary to establish the development of factory products and that there are all possibilities for this. He repeatedly mentions that the first step is to gain knowledge. [1, p. 117]

Ibrat also expressed its opinion on the need to establish a mining industry in the country. In particular, it is proposed to ensure the country's economy with the production and sale of products in accordance with foreign requirements by developing these fields, as well as to present the country to the world. The abundance of deposits of gold, silver, copper, iron, cast iron and lead, non-ferrous metals in our mountains admits that if these deposits are not processed, the state will suffer greatly. For example, he writes about medicinal plants in the country, and Afghan and Indian doctors always take us from the mountains. We need to dig more drugs. [1, p. 128] With the introduction of the above-mentioned industries, if we produce them, our cities will join and be among the big cities. These were cultural samples familiar with these objects in other cities. He emphasizes that this is what needs to be done, that it is time to try them. 
Ibrat also drew attention to the spiritual foundations of the country's development, emphasizing the need for scientific, educational and cultural work in the socioeconomic, spiritual and cultural life of the country, and created a unique concept in this regard. The model brochure focuses on primary education as the primary source of knowledge, and as long as science finds culture, science remains with the school. Without school, the whole world would be horrified, everything would be destroyed, work would be lost. [1, p. 129]

He will support the expansion of schools in the country, the introduction of compulsory education. He concludes that Turkestanis can participate widely in school only through compulsory education. Ibrat summarized his opinion, concluding that without a school there would be no culture in the world. [1, p. 114]

His thoughts are valuable today. Ibrat believes that it is necessary to try evening agriculture in the summer, open evening schools for farmers who are free in winter, appoint teachers and ensure their literacy during the three-month winter season. In the village, this can be done in two ways - strengthening neighbouring schools and opening evening schools instead of classrooms, reforming the old school, instructing the teacher who teaches in letters and pens, or imam, his own local expenses, food, house - the place could be taken in absentia and taken to different courses. According to him, under this pretext literacy will increase.

Also, there is the idea that culture can flourish only if there are at least ten schools in the village instead of ten, given evening teachers instead of evening meetings, which contributes to the benefits of disseminating knowledge among people in such ways. [1, p. 133-134]

It should also be noted that at the same time there were heated discussions in the country about the prevention of illiteracy, schools, and education. The writing of this work by lbrat shows his attitude to these debates and discussions. Evening schools organized according to his idea lasted until the last days. In the brochure, given the establishment of a girls' school based on national customs and traditions in villages, this may be a little more difficult and then explain the reasons for this. it takes at least fifty years for that regret to disappear. [1, p. 135]

For example, he hoped that in order to attract more women and girls to school for girls as soon as possible, it was necessary to use literate rural nurses in order to "in five to ten years... in each village five to ten teachers were ready. " Noting that more female teachers should be involved, she considered it the most convenient way to educate girls. It is clear that Is'hakhon was a supporter of the active participation of women, who form the basis of the nation, in public life. In the brochure, Ibrat puts forward the idea of creating vocational schools as a necessary scientific institution for introducing products in factories and factories. Why were professional schools needed during this period? He needs personnel at small industries, small enterprises, factories and factories in the country. Therefore, Ibrat believes that they need a vocational school and a chemical, medical, engineering, business. [1, page 136]

Is'hakhon believes that the country's need for personnel in the industrial sector can be met through the creation of vocational schools. Therefore, Ibrat's thoughts on industrial production, which is one of the sectors of the economy, implying that in order to carry out 
this work, it is necessary to first create local higher education institutions. Because at that time only in Tashkent in Central Asia Semenov A.A. The organization was the Central Asian State University, founded in the fall of 1920 [13]. We see the implementation of this idea of higher education on the example of creating higher educational institutions in Ferghana, Andijan, Namangan, Samarkand, Jizak, Karshi and Urgench. The play also says about higher education institutions: "There is hope that more students will enter if higher education courses are opened in our cities. Studying abroad is more difficult. He reads in front of his parents instead, and this will happen, inshallah "[1, p. 118]

This indicates that Is'hakhon cares about the training necessary for the development of the country. The only way to solve this problem is to educate students and then place them on the spot. To do this, he says, the government needs to keep pace with education, send students to courses, replace those who came from them and then develop culture. It is clear from these ideas that Ibrat believes that for the development of the country, first of all, it is necessary to eradicate illiteracy and ignorance. He argues that the development of a nationstate can be achieved only when among our people there are educated national intellectuals who know the basics of science and technology.

The author also puts forward the idea of the need for research institutes, believing that if master chemists extract ore, gold, silver, copper, iron, cast iron, lead, medicines and paints from stones, then our culture will be improved. experts believe that this can only be done based on the results of joint scientific discoveries [1, p. 118-119] The author not only explains the need for schools and universities, education is the first problem to be solved, but also measures to create these schools, the problem of financing, as well as the equipment necessary for schools. research institutes emphasize that the state should be the main reformer in organizing this work in evening schools. Therefore, all people now know what science is, and the actions of our government must take good steps. But you should continue, the unemployed child will not be a scientist. If our education department and schools had followed this path, we would have entered the culture in ten years - [1, p. 134-135]

The brochure also mentions the opening of adult schools in rural areas, and Ibrat calls for the rejection of the method of waiting for funding from the government. This would help school and education, even if the efforts of those wishing to study in organizing these events themselves, he writes. The questions raised in the brochure formed the spiritual basis of the young state, which at one time declared independence, and are closely related to today's reforms.

Ibrat also addresses the problem of state supplies to the brochure and recognizes that it learns from the experience of foreign countries when creating them. In this case, referring to the experience of foreign engineering firms, in the cities they saw, the government had a construction court in which engineers built the building in accordance with the application filed by people and paid the costs in accordance with the rules. Engineers calculate the costs of the application and inform the landlord, who then, with his consent, pays the rent for several years only after the three-room houses are built within a month and even running water will be on the top floor. This justification assumes that the government receives money from buildings and that the state budget is large within the city through which its finances are paid [1, p. 132] At the 
same time, Ibrat calls on our country to learn from the experience of businessmen and entrepreneurs of foreign companies in doing business. In his work, the author emphasizes the need to pay attention to publishing. "Given Ferghana's abundance of superstitions," he writes, "we had to print and distribute three or four books a year." But none. The weekly school required at least one magazine and brochure. This would serve to spread science by criticizing things that do not fit into the scale of the same mind. It was useful to progressive elders and teachers as a model of culture, and advertisements were published there. We will have a way, there are works useful to the people that will leave to those who come after us "[1, p. 138] He believes that these ideas cannot make progress unless the world's scientific and technological advances are mastered, fully understood and acted upon.

Ibrat's work in the field of culture and development was reflected in the press movement, and, like many progressive Jadids, he praised the role of the newspaper in the rapid dissemination of educational and cultural news, and in 1913 asked the government to publish "Altijoral-Namangan" under the leadership of "Matbai Is'haki". This was reported by the newspaper "Vaqt" which is published in Ufa in Central Asia and in the Turkic world as a whole: "Namangan. Judge Is'hakhon filed an application for publication of the newspaper "Altijoral-Namangan". We sincerely wish you success. "[14] In conclusion, he lists a number of his works on science, education and culture, development. In particular:... " the benefits of new works for the people and school, such as: "Tarihi Farg'onai umroni", a poem, "Tarihi hurriyat", "Mezon ul-zamon”, “Lug'ati sitta-al-sina”, "Jome ul-hutut”, “Qo'rboshilar zamoni”, "Tarihi madaniat". These are all national books. Nevertheless, "Devoni Ibrat" is a collection of historical poems that have been collected for more than thirty years, most of which are historical, national poems and moral criticism.

These are all national books. However, the "Devoni Ibrat" gazelle is a collection of historical poems that have been collected over thirty years, most of which are historical, national poems and moral criticism, a collection of gazelles about our events that have not yet been published or published. I am currently interested in the translation of the book of Arabic medicine "Tazkirai Suvaido" into Turkish. The work of "Tarjimai holim" was ready. This is a good historical story about travelling to Afghanistan, India, Arabia. [1, p. 139]

In addition, the pamphlet tells about the work "Jome ul hutut", published in 1912 by "Matbaai ishaqiya".... "This behaviour was the history of the ancients. Two thousand copies were printed and remained in the printing house. [12] Now we have less. They ask a lot of people, but we say no."

The "Mezon ul-zamon" Is'hakhon is also mentioned in the "Historical Culture" of Ibrat, which does not indicate the time of its writing, but is listed among other works, such as "Benefits for the People and School" [1, p. 139] These works of Ibrat have scientific value as a historical heritage. Ibrat also briefly talks about his work "The History of Freedom", which is not yet in the work. According to him, this work was poetic and was written before the overthrow of the old government and the formation of a new government. For example, its content is propaganda about culture. In the author's work, instead of gaining freedom at that time, the rich Namangan quarrelled with each other, and when there was a serious and long-standing conflict, they did not work for autonomy. This work takes 45 pages and gives good information to everyone who wants to 
know the events that took place before the revolution. From this opinion of the author, some information can be obtained about the work "Tarixi hurriyat" and its content. In his "History and Culture", Ibrat briefly describes the bloody clashes between the independence movement and the government in the Ferghana Valley since 1918. He first describes his attitude to history as follows: "History tells the story every time." [1, p. 123-124]

When considering works written in the 1920s, it is necessary to recognize that the dominant communist ideology, although not completely rooted in the literature of that period, in a sense had a serious influence. The country's intelligentsia believed in the original promises and slogans of the Soviets. Therefore, although Is'hakhon admits in the play that the independence movement began a year after the revolution, he does not give any information about the bloodshed of Kokand autonomy. [1, p. 124-125]

Is'hakhon, in turn, dwells in detail on the war waged by the government against independence fighters. From his thoughts, it is clear that Ibrat believed in the promises that he made in the slogans of the Soviets, which in some sense seriously influenced his worldview. This was reflected in his later activities in Soviet schools. The author admits that he detailed these facts in the work "Frog Age" and writes that "let them read our work, of course, they will remain satisfied" [1, p. 126-127] From this, it can be seen that this work contains events related to the history of independence of the Ferghana Valley in 1918-1924, and these two books have not survived to this day.

\section{CONCLUSION}

In conclusion, Ibrat's work "Historical Culture" is devoted to the problem of creating both the material and spiritual basis of an independent state. In the brochure, Ibrat states that the material basis of state development is the development of local industry, the construction of irrigation facilities, agriculture in the country, domestic and foreign trade, minerals in the country, the organization of their processing, the production of finished products instead of raw materials. mentions problems. The question is raised of the creation of schools, including women's, evening, multidisciplinary vocational schools, universities, research institutes, publishing houses, firms of various specialities, including engineering, as the spiritual basis for the development of the state. In particular, he urges our people to adopt the experience of businessmen and entrepreneurs of foreign companies.

In February 1926, the first congress of education and culture workers of the republic was held in Samarkand, to which Is'hakhon Ibrat from Namangan was sent as a deputy. This congress aims at educators and cultural figures to open new schools and involve women in public, public and educational work. Since the issue of education is the most important issue on the agenda, Is'hakhon draws attention to this in his book "Historical Culture", written this year. In the brochure, Ibrat discusses science, technology, women's problems, attitudes to science and ways to implement them in the country [1, p. 136-137] The difference between the book and other historical works is that the author does not use works or any documents written before him as a historical source, but sets out his point of view based on what he saw and knew as a person of that period. His approach to problems was based on a comparison of the lives of the peoples of the West and the East. Thus, the author's foreign travel plays an important role in his social life, his efforts to raise the standard of living and the appearance 
of his works. Since the brochure was devoted to the problems of creating the foundations of a national state as the first attempt to introduce it in the country, the pursuit of nationalism was condemned as nationalism and could not get out of the control of the Soviet regime for 20 years. The fact that since the 1920s, "indifference to the intelligentsia of indigenous peoples, restriction of them from various social occupations, placing ideological labels as non-intellectual, harmful" and the repression of Ibrat under the label of the enemy of the people - all this reveals the essence of Soviet politics [15].

Today is preparing for the publication of Is'hakhan's Historical Culture. No wonder it'll be sold out soon.

\section{REFERENCES}

1. Junaydullohxo'ja o'g'li I.I. (1916). History of Fergana. Tashkent: Institute of Oriental Studies of the Academy of Sciences of the Republic of Uzbekistan. Q. inv.№ 11616 p.139.

2. Alimova D.A. (1993). From the history of the study of cultural problems in Uzbekistan in the first thirty years of the XX century. Social Sciences in Uzbekistan,

3. Junaydullohxo'ja o'g'li I.I. (1905). Letter from Namangan County. Turkiston viloyatining gaziti, p. 2.

4. Junaydullohxo'ja o'g'li I.I. (1907). Letter to the Editor. Turkiston viloyatining gaziti, $\mathrm{p}$. 2.

5. Junaydullohxo'ja o'g'li I.I. (1908 йил 13январ). Letter to the editor. Turkiston viloyatining gaziti.

6. Junaydullohxo'ja o'g'li I.I. (1910). Regarding the election of official natives in Namangan. Turkiston viloyatining gaziti.

7. Junaydullohxo'ja o'g'li I.I. (1911). Namangan railway. Turkiston viloyatining gaziti.
8. Junaydullohxo'ja o'g'li I.I. (1912). Jome ul hutut. Namangan :: Matbaai Is'haqiya. Institute of Oriental Studies of the Academy of Sciences of the Republic of Uzbekistan. Q. funds. Inv. № - 621 .

9. Junaydullohxo'ja o'g'li I.I. (1913). From the newspaper Vaqt. Turkiston viloyatining gaziti.

10. J Junaydullohxo'ja o'g'li I.I. (1901). Dictionary Sitta-al sina. Tashkent: Ilin. p.2.

11. Junaydullohxo'ja o'g'li I.I. (1908). San'ati Ibrat Qalami Mirrajab Bandiy. To'raqo'rg'on: Matbaai Ishoqiya.

12. Junaydullohxo'ja o'g'li I.I. (1912). Jome ul hutut. Namangan :: Matbaai Is'haqiya. Institute of Oriental Studies of the Academy of Sciences of the Republic of Uzbekistan. Q. funds. Inv. № -621.

13. Alimova D.A. (1995). From the history of the study of cultural problems in Uzbekistan in the first thirty years of the XX century. Social Sciences in Uzbekistan, №1 p.10.

14. Burkhonov, I. M. (2020). Zakat has ensured fairness and balance in society. ISJ Theoretical \& Applied Science, 05 (85), 201204.

15. O., Sharafiddinov. (1993). Mustafo Cho'qay, Cho'Ipon, Otajon Hoshim. Votees of independence. Tashkent: Sharq. p.5.

16. Kosimova, S. H., \& Kosimov, L. M. (2020). Principles of forming a garden-park landscape design around historical monuments of the fergana valley. ACADEMICIA: An International Multidisciplinary Research Journal, 10(6), 1582-1589.

17. Nazirjonovna, H. Z., \& Sobirjonovna, Q. D. (2020). Important sources in studying the tax system of the Kokand Khanate. ACADEMICIA: An International Multidisciplinary Research Journal, 10(5), 803-808. 
18. Muhiddinovich, B. I. (2020). Negative impact of the tax system on political life-on the example of the history of the Kokand Khanate (1850-1865). ACADEMICIA: An International Multidisciplinary Research Journal, 10(5), 790-795. 